\title{
Proximate, Phytochemical and Micronutrient Composition of Sida acuta
}

\author{
Raimi, Monsurat M. , Oyekanmi, Adeyinka M. , And Adegoke, Bosede M. \\ Department of Applied Sciences, Osun State Polytechnic, P.M.B. 301, Iree, Nigeria.
}

\begin{abstract}
Sida acuta, a shrub belonging to Malvacea family, is widely distributed in pan tropical areas and it has many folk medicine applications that varies from one region to another. The proximate, phytochemical and micronutrient (minerals and vitamins) composition of Sida acuta leaves were determined and quantified in this study using standard analytical methods. The result for proximate composition $(\%)$ was $9.03 \pm 0.06,19.13 \pm 0.15$ $0.67 \pm 0.06,6.33 \pm 0.06,9.50 \pm 0.01$ and $55.30 \pm 0.10$ for moisture, protein, fat, ash, fibre and carbohydrate respectively and values obtained for the phytochemicals were $125.0 \pm 0.00 \mathrm{mg} / 100 \mathrm{~g}$ tannin, $406.67 \pm 2.89 \mathrm{mg} / 100 \mathrm{~g}$ saponin, $1751.67 \pm 2.89 \mathrm{mg} / 100 \mathrm{~g}$ alkaloid, $1255.0 \pm 0.0 \mathrm{mg} / 100 \mathrm{~g}$ flavonoids, $85.0 \pm 0.0 \mathrm{mg} / 100 \mathrm{~g}$ terpenoids and $90.0 \pm 0.0 \mathrm{mg} / 100 \mathrm{~g}$ phenolics. The result of micronutrient analysis gave $22.43 \pm 0.21 \mathrm{mg} / 100 \mathrm{~g}$, $0.33 \pm 0.06 \mathrm{mg} / 100 \mathrm{~g}, 0.10 \pm 0.0 \mathrm{mg} / 100 \mathrm{~g}, 0.02 \pm \mathrm{mg} / 100 \mathrm{~g}$ and $925 \pm 0.0 \mathrm{mg} / 100 \mathrm{~g}$ for ascorbic acid, niacin, thiamin, riboflavin and $\beta$-carotene, respectively, and the values for calcium, iron, phosphorus, sodium and magnesium were $85.0 \pm 0.0 \mathrm{mg} / 100 \mathrm{~g}, \quad 4.867 \pm 0.06 \mathrm{mg} / 100 \mathrm{~g}, \quad 65.0 \pm 0.0 \mathrm{mg} / 100 \mathrm{~g}, 110 \pm 0.0 \mathrm{mg} / 100 \mathrm{~g}$ and $24.5 \pm 0.0 \mathrm{mg} / 100 \mathrm{~g}$ respectively. The phytochemical composition of Sida acuta are in significant quantities to confer diverse therapeutic effects while the values for proximate and micronutrient composition indicate that Sida acuta would provide beneficial nutrients.
\end{abstract}

Keywords: Mineral, phytochemical, proximate, Sida acuta, vitamin

\section{Introduction}

Plants are the basic source of knowledge of modern medicine. The burgeoning worldwide interest in medicinal plants reflects recognition of the validity of many traditional claims regarding the value of natural products in health care [1]. Several plants of diverse origins have been exploited by trial and error over many generations for therapeutic purposes. In Africa and in most of the developing countries, plants' properties are empirically appreciated. The adverse effects of chemical drugs, their increasing costs and greater public access to information on traditional medicine have also led to an increase in interest in alternative treatments. The reason is that traditional medicine is a medicine of proximity, less constraining and non-expensive [2]. The importance of herbs in the management of human ailments cannot be overemphasized. It is clear that the plant kingdom harbours an inexhaustible source of active ingredients invaluable in the management of many intractable diseases [3]. Traditional medicines are used by about $60 \%$ of the world population in both developing and developed countries where modern medicines are predominantly used while an estimated 60$80 \%$ Africa's population depends solely on herbal remedies for its primary health care needs [4].

Phytochemicals from medicinal plants serve as lead compounds in drug discovery and design. WHO report depicts that more than $80 \%$ of world's population rely on plants based products to meet their health needs [3]. Today, it is estimated that plant materials are present in or have provided the model for $50 \%$ western drugs. Many commercially proven drugs used in modern medicine were initially used in crude form in traditional or folk healing practices or for other purposes that suggested potentially useful biological activity [5].

In diversity, plants are thought to be between 250,000 to 400,000 species spread across all continents from the Antartic to the Artic [4] and Africa has arguably one of the richest phytodiversities in the world. Africa's forests geographically span approximately 216, 634, 000 ha [6]. Near about 13000 plant species are medicinally important worldwide. 3500 plant species in India are useful as a source of crude drug. Near about 2500 plants are ethnomedicinally important. Out of it, genus Sida is one of the important groups of plants [7].

The genus Sida belongs to family Malvacea. The plants are mostly weeds which are observed roadside, coastal areas, forests, fields e.t.c. Sida acuta is very common weed which is also useful in ajurveda. It is used in the treatment of malaria, diarrhea, asthma, headache, cold, fever, skin diseases and facial paralysis [7]. Sida acuta (Malvaceae) is an erect perennial shrub found throughout the hotter parts of India and Nelpal. It is used for various medicinal purpose such as liver disorders, diuretic and abortifacient in ayurvedic preparations, asthma, fever, headache (migraine), cough, cold, ulcer, antihelminthic, snake bite, urinary diseases, female disorders, antifertility agent and sedative. The aerial part of the plant is most frequently used part [3]. It is widely distributed in wasteland and creeks of Taiwan. It has been used as a folk medicine for treating snake bite [8]. In Central America, it is used to treat renal inflammation, cold, fevers, headache, ulcer and worms [9]. The juice of the leaves is boiled in oil and applied to testicular swellings and in elephantiasis. In the Philliphines, 
leaves are employed for making poultices for sores [10]. Sida acuta (Malvaceae) is an erect, branched small perennial herb or small herb growing abundantly in Nigeria. It is commonly known as wire weed because of the resilience of the plant. In the southern part of Nigeria, the plant is used to hasten delivery, treat malaria, jaundice and as anti-inflammatory and hypoglycemic agent [11]. Increased awareness of the significance of medicinal plants and nutrition to the health of individuals and communities has necessitated the need for knowledge of the food nutrients and phytochemicals presents in the various parts of different plants. The phytochemicals contained in the plants are largely responsible for the definite physiological activity they exert on human body and their nutritional value is determined by the food nutrient they contain [12].

The proximate, phytochemical and micronutrient (vitamin and mineral) composition of Sida acuta leaves were investigated in this study.

\section{Materials}

\section{Materials And Methods}

Sida acuta plant were obtained from the campus ground of Osun State Polytechnic, Iree, Nigeria. The leaves were plucked off the plant stem, cleaned under running tap water and air dried for two weeks. The dried leaves were ground into a powder (40 mesh size) and kept in airtight containers under dry conditions prior to analysis.

\section{Methods}

Proximate analysis of moisture, protein, fat, crude fiber and carbohydrate contents were carried out according to the procedures of Association of Official Analytical Chemist (A.O.A.C.) [13]. Phytochemical screening for tannins, saponins, alkaloids, flavonoids, terpenoids and phenolics were as described by Sofowora, [14]. Procedures according to Marcano and Hasegawa [15] were employed for quantification of tannins, saponins, alkaloid, flavonoids, terpenoids and phenolics composition. Micronutrient composition analysis for vitamin (ascorbic acid, niacin, riboflavin and $\beta$-Carotene) composition were determined according to the methods described by Okwu and Josiah, [16] while mineral (calcium, iron, phosphorus, sodium and magnesium) composition analyses were determined according to the methods described by Gafar et al., [17]. All analyses were done in triplicate and reagents used were of analytical grade. Result values of different parameters were expressed as the mean value \pm standard deviation.

\section{Results}

The results obtained in this study for proximate composition, qualitative tests for phytochemicals and phytochemical composition are as shown in Tables 1,2 and 3 respectively while Tables 4 and 5 present the values obtained for micronutrient analysis for vitamins and minerals composition respectively.

Table 1: Proximate composition of Sida acuta

\begin{tabular}{lc}
\hline Parameter & Composition (\%) \\
\hline Moisture content & $9.03 \pm 0.06$ \\
Protein & $19.13 \pm 0.15$ \\
Fat & $0.67 \pm 0.06$ \\
Ash & $6.33 \pm 0.06$ \\
Fibre & $9.50 \pm 0.10$ \\
Carbohydrate & $55.30 \pm 0.10$ \\
\hline
\end{tabular}

Values are mean of triplicate determinations \pm standard deviation (S.D) 
Table 2: Qualitative Test for Phytochemicals in Sida acuta

\begin{tabular}{lc} 
Phytochemical & Status \\
\hline Tannins & +++ \\
Saponins & ++ \\
Alkaloids & ++ \\
Flavonoids & ++ \\
Terpenoids & ++ \\
Phenolics & +++ \\
\hline & \\
\hline+++ Highly present +++ Moderately present
\end{tabular}

Table 3: Phytochemical composition of Sida acuta

\section{Phytochemical}

Tannins

Saponins

Alkaloids

Flavonoids

Terpenoids

Phenolics
Composition (mg/100g)

$125.00 \pm 0.00$

$406.67 \pm 2.89$

$1751.67 \pm 2.89$

$1255.00 \pm 0.00$

$85.00 \pm 0.00$

$90.00 \pm 0.00$

Values are mean of triplicate determinations \pm standard deviation (S.D)

Table 4: Vitamin composition of Sida acuta

\begin{tabular}{lc}
\hline \multicolumn{1}{c}{ Vitamin } & Composition \\
\hline Ascorbic acid & $22.43 \pm 0.21(\mathrm{mg} / 100 \mathrm{~g})$ \\
Niacin & $0.33 \pm 0.06(\mathrm{mg} / 100 \mathrm{~g})$ \\
Thiamin & $0.10 \pm 0.00(\mathrm{mg} / 100 \mathrm{~g})$ \\
Riboflavin & $0.02 \pm 0.01(\mathrm{mg} / 100 \mathrm{~g})$ \\
$\beta$-Carotene & $925 \pm 0.02(\mu \mathrm{g} / 100 \mathrm{~g})$
\end{tabular}

Values are mean of triplicate determinations \pm standard deviation (S.D) 
Table 5: Mineral composition of Sida acuta

\begin{tabular}{cc}
\hline Mineral & Composition (mg/100mg) \\
\hline Calcium & $85.0 \pm 0.00$ \\
Iron & $4.87 \pm 0.06$ \\
Phosphorus & $65.0 \pm 0.00$ \\
Sodium & $110.0 \pm 0.00$ \\
Magnesium & $24.5 \pm 0.00$ \\
\hline Values are mean of triplicate determinations \pm standard deviation (S.D)
\end{tabular}

\section{Discussion}

The moisture content value of $9.03 \%$ obtained for Sida acuta leaves in this study (Table 1) is low and it suggests that the leaves can be kept for a relatively long time. The moisture content of any food can be used as a measure of its keeping quality [18]. This value is lower than those of Combretum zenkeri (11.325\%) [18], and Hymenocardia ulmoides $(67.20 \%)$ and Vitex ferruginea $(55.41 \%)$ [19], higher than those reported for Piliostigma thonningii (4.6\%) [12], Tylophora glauca (7.11\%) [5], and similar to those of Moringa (M. Oleifera) $(9.533 \%)$ [20 ].

A protein content value of $19.13 \%$ obtained for Sida acuta is in multiples of values earlier reported for Cabbage $(1.21 \mathrm{~g} / 100 \mathrm{~g})$, Lettuce $(1.62 \mathrm{~g} / 100 \mathrm{~g})$, Celery leaves $(3.46 \mathrm{~g} / 100 \mathrm{~g})$ and leaf parsley $(2.97 \mathrm{~g} / 100 \mathrm{~g})$ [21], Aloe barbadensis (4.73\%) [4] and Aloe vera leaves (6.86\%) [1]. The values reported for C. zenkeri, Amaranthus asper, I. glauca and Moringa were 20.5398\% [18], 11.13\% [23], 20.03\% [5] and 30.29\% [20]. Thus, $S$. acuta can be termed protein rich and may serve a source of dietary protein supplementation, a nutritional significance.

A percentage fat composition of $0.67 \%$ characterize $S$. acuta as a low fat source. Earlier studies have reported $0.27 \%, 2.27 \%, 2.91 \%, 3.68 \%, 4.0 \%$ and $6.5 \%$ fat composition for leaves of A. barbadensis [4], $C$. zenkeri [18], A. vera [1], Momordica charantia [22], A. asper [23] and Moringa [20] respectively.

An ash content value of $6.33 \%$ was obtained in this study. $0.1386 \%, 2.36 \%, 7.64 \% 15.42 \%$ and $18.5 \%$ ash content values were reported in earlier studies for leaves of C. zenkeri [18], A. barbandensis [4], Moringa [20] (Moyo et al., 2011), M. charantia [22] and A. asper [23] respectively.

Its fibre content is $9.50 \%$. Adequate intake of dietary fibre can lower the serum cholesterol level, risk of coronary heart disease, hypertension, constipation, diabetes, colon and breast cancer [23]. The fibre content values reported for leaves of Saba florida [24], M. chanrantia [22], and Acalypha hispida, Acalypha racemosa and Acalypha marginata [25] were 4.3\%, 3.31\% and 10.25\%, $7.20 \%$ and $11.50 \%$ respectively.

S. acuta is a very good source of carbohydrate given a percentage composition of $55.30 \%$ (Table 1). Carbohydrate provides energy to cells in the body particularly the brain, the only carbohydrate dependent organ on the body [18]. The leaves of Piper umbellatum and Peperomia pellucida, Commelian africana and Ageratum conyzoides, $P$. thonningii and, $H$. ulmoides and $V$. ferruginea were reported to have carbohydrate content values of $38 \%$ and $42 \%$ [26], 34.35\% and $33.37 \%$ [2], 65.28\% [12] and, 8.57\% and 4.53\% [19] respectively.

The results of phytochemical (qualitative and quantitative) constitution of $S$. acuta leaves are as shown in Tables 2 and 3. Phytochemicals are secondary metabolites of plants known to exhibit diverse pharmacological and biochemical effects on living organisms. The phytochemicals, tannins, saponins, alkaloids, flavonoids, terpenes and phenolics were found to be present in $S$. acuta leaves and are in amounts to be of medicinal value. Many plants containing alkaloids and flavonoids have diuretic, antispasmodic, anti inflammatory and analgestic effects [18]. Alkaloids are capable of reducing headache associated with hypertension. It has been reported that alkaloids can be used in the management of cold, fever and chronic 
catarrh. Flavonoids are known for their antioxidant activity and hence they help to protect the body against cancer and other degenerative diseases [26]. Flavonoids have been shown to have antibacterial, antinflammatory, antiallergic, antimutagenic, antiviral, antineoplastic, antithrombotic and vasodilatory activity [25].

Tannins are known to exhibit antiviral, antibacterial and antitumor activities. It was also reported that certain tannins are able to inhibit HIV replication selectively and is also used as diuretic [12]. Tannins are well known for their antioxidant and antimicrobial properties as well as for soothing relief, skin regeneration, as anti inflammatory and diuresis. Saponins are expectants, cough depressants and adminstered for hemolytic activities [26].

In medicine, saponin is used as hypercholesterolemia, hyperglycaemia, antioxidant, anticancer, anti inflammatory and weight loss. It has also been reported to have antifungal properties [12]. Saponins exhibit cytotoxic effect and growth inhibition against a variety of all making them have antinflammatory and anticancer properties [25].

Terpenes are very important group of organic compounds that have been reported as potent drugs used in treatment of wide range of ailments. The most rapidly acting anti malarial Artemisin and its derivates are terpenes [12]. Phenols also found present in plant sources are major group of compounds acting as primary antioxidant or free radical scavenger [4]. The efficacy of the utilization of $S$. acuta leaves in herbal/ traditional/ folklore medicine may be attributed to its phytochemical profile.

The leaves of $S$. acuta possess significant quantities of fat soluble vitamin A precursor, $\beta$-Carotene and water soluble vitamins - ascorbic acid, niacin, thiamin and riboflavin as presented in Table 3. Vitamins are a diverse group of organic molecules required in very small quantities in the diet for health, growth and survival. The absence of vitamin from the diet or an inadequate intake results in characteristics deficiency signs and ultimately death [22].

Vitamin A is a component of the visual pigments in the retina, regulates gene expression and cell differentiation. The deficiency may lead to night blindness, xeropthlamia, keratinization of skin [22]. Vitamin C maintains blood vessel flexibility and improves arteries circulation in the arteries of smokers. The most important benefit claimed for vitamins $\mathrm{A}$ and $\mathrm{C}$ is their role as antioxidants in which they scavenge oxygen free. These chemically active particles are byproducts of many of body's normal chemical processes. Their numbers are increased by environmental assaults such as smoking, chemicals, toxins and stress [18]. Vitamins C helps the body to absorb iron and to breakdown histamine, the inflammatory components of many allergic reactions [27].

Deficiencies of the energy releasing vitamins (thiamin, niacin, riboflavin) produce a number of overlapping symptoms. A deficiency of niacin causes pellagra in man and is characterized by 3D's namely dermatitis of the exposed parts, diarrhea and dementia [28]. Symptoms of thiamin deficiencies depends on the severity - mild deficiency; loss of apetite, fatigue, constipation, moderately severe deficiency; mental confusion, opthalmoplegia, and severe thiamin deficiency; dry and wet beriberi [29]. Riboflavin (Vitamin $B_{2}$ is synthesized by all green plants, most bacteria, yeast and moulds. Animals have so far not been shown to synthesize riboflavin. Persons deficient in vitamin $\mathrm{B}_{2}$ show cheilosis, glossitis, keratitis, corneal vascularization and seborrheic dermatitis [28].

Mineral $(85.0 \pm 0.0 \mathrm{mg} / 10 \mathrm{mg}$ calcium, $4.87 \pm 0.06 \mathrm{mg} / 100 \mathrm{~g}$ iron, $65.0 \pm 0.0 \mathrm{mg} / 100 \mathrm{~g}$ phosphorous, $110 \pm 0.0 \mathrm{mg} / 100 \mathrm{~g}$ sodium and $24.5 \pm 0.0 \mathrm{mg} / 100 \mathrm{~g}$ magnesium) composition of $S$. acuta are as presented in Table 4. Calcium is an essential nutrient required for critical biological functions such as nerve functions, blood coagulation, structural supporting of the skeleton, cell adhesiveness mitosis and muscle contracts. It is partly responsible for solidity as well as movement of the body. Calcium aids digestion and promote good growth and vigor by helping to regulate metabolism [27]. Phosphorus has been reported to be good for bones and teeth formation. It contributes to energy production by participating in the breakdown of carbohydrates, protein and fats. It is needed for growth, maintenance and repair of tissues and cells and for the production of DNA and RNA [5].

Iron is a necessary component of hemoglobin and myoglobin for oxygen transport and cellular processes of growth and division. Iron is also an essential trace element for normal functioning of the central nervous system and in oxidation of carbohydrates, proteins and fats [20]. Sodium is an important mineral in the body fluid and in the maintenance of electric potential in the body tissue. Magnesium plays essential role in calcium metabolism in bones and also involve in prevention of circulatory diseases. It helps in regulating blood pressure and insulin releases [30]. Magnesium is necessary for major biological processes, including the production of cellular energy and the synthesis of nucleic acids and proteins [5]. The composition of calcium, iron, phosphorous, sodium and magnesium in $S$. acuta leaves as obtained in this study indicates that nutritional benefits would be derived in addition to utilisation of $S$. acuta leaves for medicinal purposes. 


\section{Conclusion}

The investigation into proximate and micronutrients composition of Sida acuta leaves in this study has shown S. acuta to be composed of significant amounts of essential food nutrients. These food nutrients are in amounts comparable to those of leafy vegetables which are commonly consumed for good nutrition. The phytochemical constitution and composition of $S$. acuta are in amounts to be responsible for diverse medicinal and therapeutic purposes. Sida acuta leaves would provide nutritional benefits and medicinal value.

\section{References}

[1] M. Ahmed and F. Hussain. Chemical Composition and Biochemical Activity of Aloe Vera (Aloe Barbadensis Miller) Leaves. International Journal of Chemical and Biochemical Sciences, 3(5), 2013, 29-33

[2] O.S Agunbiade, O.M. Ojezele, J.O. Ojezele and A.Y. Ajayi. Hypoglycaemic activity of Commelina africana and Ageratum conzyzoides in relation to their mineral composition. African Health Sciences, 12(2), 2012, $198-203$

[3] M. B. Palaksha and K. Ravishankar. Phytochemical Screening and Evaluation of in vitro Antibacterial and Antihelminthic Activities of Sida acuta Leaf Extracts. Journal of Chemical and Pharmaceutical Research, 4(11), 2012, 4757 - 4761

[4] A.O. Adesuyi, O. A. Awosanya, F. B. Adaramola and A.I. Omeonu . Nutritional andPhytochemical Screening of Aloe barbadensis. Current Research Journal of Biological Sciences, 4(1), 2011, 4 - 9

[5] V.A. Ajibade and E. D. Fagbohun. Physicochemical, Proximate Analysis and Antimicrobial Activities of Methanolic Crude Extract of Tylophora glauca (Bullock.) Journal of Pharmaceutical and Biomedical Sciences, 1(1), 2010, 7-12

[6] I. I. Ijeh and C. E. C. C. Ejike. Current Perspectives on the Medicinal Potentials of Vernonia amygadalina, Del. Journal of Medicinal Plants Research, 5(7), 2011, 1051-1061

[7 ] R. R. Wake. In vitro Antimicrobial Activity of Extracts of Plants of Genus Sida Linn. International Journal of Pharmaceutical Research and Development, 3(11),2012, 210-214.

[8 ] C. Chen, L. Chao, M. Pan, Y. Liao and C. Chang. Tocopherols and Triterpenoids from Sida acuta. Journal of the Chinese Chemical Society, 54, 2007, 41-45

[9] T. A. Tor-Anyiin and K. A. Danisa. Phytochemical Screening of a Vended Antimalarial: Malatreat. Indoglobal Journal of Phamaceutical Sciences, 2(2), 2012, 98-102

[10] S. Akilandeswari, R. Senthamarai, R. Valarmath, S. Shanth. and S. Perma. Screening of Gastric Antiulcer Activity of Sida acuta Burm. International Journal of Pharmtech Research, 2(2),2010, $1644-1646$

[11] C. N. Okwuosa and N. C. Azubike and I. I. Nebo. Evaluation of the AntihyperglycemicActivity of the Crude Leaf Extracts of Sida acuta in Normal and Diabetic Rabbits. Indian Journal of Novel Drug Delivery, 3(3), 2011, 206-213

[12] M. A. Tijjani, F. I. Abdurahman, S.W. Buba, G. I. Mala, J. C. Akan, B. M. Aji and A. S. Abdullahi. Chemical and Proximate Contents of Methanolic Leaf Extract of Piliostigma thonningii schum (Camel Foot). Journal of Chemical and Pharmaceutical Research, 4(5), 2012, $2409-2414$

[13] A.O.A.C., Official Methods of Analysis. Association of Official Analytical Chemists. $15^{\text {th }}$ Edition, 1990 Washington, D.C

[14] Sofowora A. Medicinal plants and traditional medicine in Africa. (Ibadan, Spectrum books Limited, 2005) $3^{\text {rd }}$ ed., pp. 199

[15] L. Marcano and D. Hasegawa. Analysis of Phytochemicals in Leaves and Seeds. Agronomy Journal, 83, 1991, 445-452

[16] D. E. Okwu and C. Josiah. Evaluation of the Chemical Composition of Two Nigerian Medicinal Plants. African Journal of Biotechnology, 5(4), 2006, 357-351

[17] M.K Gafar, A.U. Itodo and D.S. Senchi. Nutritive and Antinutritive composition of Chanca pledra. Food and Public Health, 2(2), 2012, 21-27.

[18] C. O. Ujowundu, O. E. Okafor, N. C. Agha, L. A. Nwaogu, K. O. Igwe and C. U. Igwe. Phytochemical and Chemical Composition of Combretum zenkeri Leaves. Journal of Medicinal Plants Research, 4(10),2010, 965-968

[19] M. Andzouana and J.B Mombouli. Chemical Composition and Phytochemical Screening of the Leaves of Hymenocardia ulmoides and Vitex ferruginea. Pakistan Journal of Nutrition, 10(12), 2011, $1183-1189$

[20] B. Moyo. P. J. Masika, A. Hugo and V. Muchenje. Nutritional characterization of Moringa Leaves. African Journal of Biotechnology, 10(6), 2011, 12925-12933.

[21] A. Caunii, R. Cuciureanu, A. M. Zakar, E. Tenea and C. Guichici. Chemical Composition of Common Leafy Vegetables. Studia Universitatis "Vasile Goldis", Seria Stiintele Vietii, 20(2), 2010, 45-48

[22] R. I. Bakare, O. A. Magbagbeola, A. I. Akinwande and O.W. Okunowo. Nutritional and Chemical Evaluation of Momordica charantia. Journal of Medicinal Plants Research, 4(21), 2010, 2189 - 2193

[23] J. Alinnor and R. Oze. Chemical Evaluation of the Nutritive value of Pentaclethra macrophylla benth (African Oil Bean) Seeds. Pakistan Journal of Nutrition, 10 (4), 2011, 355 - 359.

[24] J. Omale, A. A. Rotimi and B. O. J. Bamaiyi. Phytoconstituents, Proximate and Nutrient Investigations of Saba florida (benth) from Ibaji forest. International Journal of Nutrition and Metabolism, 2(5), 2010, 88-92

[25] O. M. Iniaghe, S. O Malomo and J. O. Adebayo. Proximate Composition and Phytochemical Constituents of Leaves of Some Acalypha Species. Pakistan Journal of Nutrition, 8(3), 2009, 256-258

[26] J. K. Mensah, J. O. Ihenyen and M.O. Okhiure. Nutritional, Phytochemical and Antimicrobial Properties of Two Wild Aromatic Vegetables from Edo State. Journal of Natural Products and Plant Resources, 3(1), 2013, 8-14

[27] J. Omale, O. P. Nnacheta and I. I. Ijeh. Chemical Compositions and Effects of Aqueous Extract of Cissus multistriata on some Biochemical Parameters in Albino Rats. International Journal of Pharm Tech Research, 1(3), 2009, 509-513

[28] J. L. Jain, S. Jain and N. Jain. Fundamentals of biochemistry (Ram Nagar, New Delhi: S. Chand \& Company Ltd, 2005), 991

[29] S.G. Chaney.Principles of Nutrition II: Micronutrients in T.M. Devlin (Ed), Textbook of biochemistry with clinical correlations, $6^{\text {th }}$ Ed.(Hoboken, NJ: Wiley- Liss, 2006), 1102

[30] J. Alinnor and R. Oze. Chemical Evaluation of the Nutritive value of Pentaclethra macrophylla benth (African Oil Bean) Seeds. Pakistan Journal of Nutrition, 10 (4), 2011, 355 - 359. 